\title{
China - Cooperation and rivalry in today's interdependent world: Will pandemic change the trends?
}

\author{
WOJCIECH HÜBNER*
}

Faculty of Business and International Relations, Asia Research Institute, Vistula University, 3 Stokłosy

Street, Warsaw, 02-787, Poland

(C) 2020 Akadémiai Kiadó, Budapest

\section{ABSTRACT}

The paper examines the importance of the 'Chinese factor' in today's world from the perspective of current phenomena such as particular political and economic uncertainty and also examines them against the background of processes of global cooperation and parallel unprecedented competition at the same level. Complex phenomena occurring in this area have recently been additionally disrupted by the outbreak of the COVID-19 pandemic. Will the world be different?

Globalization processes have taken place over the centuries but have gained particular importance in our present times, because we left 'the golden age' of globalization (1990-2010) already behind us. China, ever louder, talks about the need for a 'new' globalization, in line with its new aspirations as a pretender to the leadership position in the global economy. The Belt and Road Initiative, launched in 2013, has been in the centre of its vision. It has become the foundation for China's foreign policy in the horizon of at least the middle of XXI century. It was designed to re-confirm China's unprecedented economic success of the past four decades, which to a great extent could be derived from a skilful use of the 'traditional' mechanisms of globalization.

\section{KEYWORDS}

China, globalization, uncertainty, cooperation and rivalry, the Belt and Road Initiative, pandemic

\section{JEL CLASSIFICATION INDICES}

053, P47, P59

\footnotetext{
*E-mail: w.huebner@vistula.edu.pl
} 


\section{THE WORLD ON A DIFFICULT BEND}

It seems that a growing pessimism among professional observers of economic life in the world could have been identified ${ }^{1}$ as the main theme of the year 2019. Trade wars, or their proxies, have begun on various geographic fronts, and protectionist tendencies have increased, destroying the efforts of entire generations to create the conditions for free trade. There have been stagnant trends in many countries, previously-locomotives of world development. We have seen more and more detailed uncertainties about the future fate of the UK and Europe as the Brexit scenario could shed more light into the future. Mature world economic centres of development, until recently driving forces of economic growth, have visibly weakened. Most of the G-7 economies slowed their growth. In description of these processes, renowned world reports referred ${ }^{2}$ to 'increased risk,' 'protracted uncertainty,' and 'weak dynamics.' Frustrations have emerged when trying to seek suitable leaders. We were further depressed by the hanging over our heads and conscience potential new stages of world migration beyond control and by the newly realized impact of climate change on the planet.

As if these complications and complexity were not enough, at the turn of 2019/2020, a dangerous new phenomenon appeared, in fact - violently erupted spreading immediately on the globe. For some time now - everything has been changing rapidly in front of our eyes - the structural problems of the global economy and the ongoing fears have been covered (for a difficult to predict time period) by a global outbreak of the COVID-19 pandemic, which took everyone by surprise.

The potential effects of this pandemic in the medical and health protection sense (its course over time, the resilience of individual segments of society and the possibility of taking remedial measures, the percentage of deaths, the possibility of relapses in the wave of disease, the ability to produce the vaccine) are still difficult to foresee, however at the beginning of March this year the media began to warn more and more loudly, that COVID-19 will certainly infect the world economy' and the global recession becomes 'not excluded' and even very likely.'

The, then-revelations, seem very naive and overly cautious now. The Economist, in mid-May 2020, continued the topic under the motto 'globalisation is going into reverse.' In fact, within a few weeks of March and April, the world changed beyond recognition. Every text on international relations and the world seemed already obsolete without the specific perspective of the current pandemic.

Therefore, I want here to look at the economic, political and social most recent changes taking place in the world and, in the context of the reaction of societies and their leaders to the shock of the pandemic, to assess what is actually happening. Which trends will be modified and which will survive? The post-pandemic vision of the world should consider China' future as well. It is an interdependent element of the whole structure, a country, which has climbed up to the top in the last four decades and plays a pivotal role in the world economy now (China and the world....2019). A country with a new face, but is already a key, recognized international player in this new role. This new, more assertive China is not only sharing the place in the highest level of

\footnotetext{
${ }^{1}$ A Special Report by The Economist, Beware the Borg, December 2019, reflects prevailing opinions.

${ }^{2}$ See, e.g., UNCTAD (2019), IMF (2019).

${ }^{3}$ The Economist, March 5,2020; Kolodko (2020).
} 
the world structure, but has been actively challenging other world powers for its place at the top. COVID-19 has quickly confirmed how interconnected we are on one planet. It immediately became a problem of not only one country (China, where it started) and even particular continents, but rather - of the whole world.

Globalization works and always worked in two ways. Positively - it broadens the horizons of thinking beyond the local ones and it strengthens what we can achieve without such local constraints. However, there is this proverbial 'other side of the coin.' The processes that occur make our local territory less detachable from the outside environment and more exposed (for good or bad) to everything that is happening there. In antiquity and the Middle Ages, the mechanism of the historical Silk Road demonstrated for about 17 centuries the power of international trade and integrated key fragments of the then world (which is often considered as one of the greatest achievements of our civilization), but also brought the pandemic of the socalled 'black death' to Europe probably from the foothills of the Himalayas. The bacteria and the disease itself were transmitted by rats and fleas, which hooked up to wandering caravans - a symbol of the power of international trade.

Thanks to own reforms, and a skilful usage of thriving globalization, the contemporary Chinese economy has supported the growth of the world's economy for many years. However, it is also already clear now that the other way around - as if by the launching of a 'negative multiplier' as a result of irregularity on procurement and weaknesses on the supply side, together with changes in international supply chains - is also possible. For quite some time, the Asian Development Bank Institute has been promoting the idea of a great, global transformation, in which Asia and the so-called 'ACI countries' (together ASEAN, China and India) are destined to play a lead role. This is perfectly illustrated by the classic forecast (Petri - Zhai 2013) developed in the ADB Institute, see Annex 1 of this article. The gradual structural changes in favour of Asia, the ACI group, China and India, in particular, heralded a decrease in the importance of mature, richest Western countries.

This simultaneous rivalry and cooperation most often was presented in the format of bilateral relations between the US and China, however we have seen here actually a very complex arrangement of international dependencies out of which we indicated the four decisive, independent centres of the world configuration: the US, China, EU (with economies of Germany, France and - until recently - the UK, as leading economic components), as well as the Russian Federation (Hübner et al. 2018). At some point, when the Cold War was over and in the alleged absence of antagonistic political goals in the world, it seemed that even whole history (though specifically defined) came to an end. Unfortunately, the then vision of the historical trends in the world by F. Fukuyama's (1989) was naive and deeply flawed.

Our recent, post-cold-war world remained sort of shattered into two rival halves, conflicts and local wars have not been eliminated, but it was not a simple repeat of the old rivalry between the USSR and the US. Almost everything was different, enough to say that at the time of the Cold War, economic relations between the key powers was almost negligible, while today's rivalry occurs between key trade and economic partners.

We are more and more aware of the fact that we have been witnessing now a rivalry between two worlds shaped differently, which are more often referred to (among them by Babones (2016, 2017) a prominent supporter of this type of thinking) as the world order of, on the one hand, Pax Americana symbolizing America and the West (with the western world order based, among 
others, on the Washington Consensus), and, assumed to be proposed and implemented by China, the 'Pax Sinica' or 'Tian Xia' - on the other.

The recent culmination of the bilateral rivalry between the US and China happened during a gradually intensifying trade war, in the last phase of which, China made eventually some concessions accompanied by expectations of concessions on the other side. It should be noted that this phenomenon has been occurring in a strong personal context - we have relatively new and strong personalities of leaders on both sides, the US and China.

The dramaturgy of developments was highlighted by the fact that the current pandemic broke out at almost the very peak of the recent, decisive stage of the US-China trade negotiations. What can be seen on the surface now is that the rapid and violent course of the pandemic has caused considerable changes (temporarily or long-term?) in the way modern societies function. Macroeconomic cultural parameters have changed faster than under some routine adjustment and may create a 'new normal' categories and levels. Micro-scale practices of enterprises have changed. There may be significant changes in the structure of economic sectors, too. In business, new winners and losers are expected.

We could visualize the big picture in the following way:

- We have in front of us the ancient Chinese symbol of intertwined yin and yang, the two opposite but complementing forces whose interrelation is putting everything on the move whichis simultaneous interplay between rivalry and cooperation;

- These two intertwined forces must be seen with the background of the changing environment - such as the changing realities of globalization, major global projects launched, such as the Belt and Road Initiative and many other current factors and mechanisms;

- In front of the yin-yang plane, we have a big and bold arrow symbolizing the external shock of the pandemic;

- Eventually, we are interested most to see what is on the other side of the initial 'yin and yang' plane - how the shock of the pandemic goes through the many layers of our political, economic life and shapes new social relations and cultural parameters (especially in the context of the rivalry-cooperation relationship), which forces are amplified and which are on a downward trend, or even-phased out.

\section{THE CHANGING ENVIRONMENT FOR RIVALRY AND COOPERATION}

Even before the pandemic, the contemporary world was full of truly unprecedented phenomena. China has become a world power and by creating new facts of life was softly challenging the Western leadership on many fronts and even talking of a necessity of introducing a new world order protectionist tendency began to develop in the countries that had previously pioneered in fighting them. The world watched President Xi at the Davos Forum encouraging USA and its President Trump to reject protectionism and support a free-market model. Towards the end of 2019, an unprecedented trade war between the USA and China, which was developing in a style and rhythm of routine business negotiations, started culminating but was already talked about without emotion, almost like a part of everyday routine life.

Further globalization and structural change in the global economy are full of many unknowns. Certainly, the 'golden age' of globalization has already passed. The processes continue, 
but they do not develop as spontaneously and dynamically as it was once anticipated. Some experts are pointing at a major correction of globalization trends, others even talk about completely new trends in the opposite direction and declare the end of globalization as we know it. The slowdown in traditional globalization processes is often referred to as the 'slowbolization." At this stage globalization is indeed more difficult than in the past (such as in the field of the globalized services), and a local competitor seems to be much better prepared to resist competition from outside.

There is a huge spread of views and a noticeable search for the coherent logic and new criteria to describe the ongoing processes. Some see in these processes globalization of the 'G-0' type - without a clear leader and hegemon, others see primarily a world split into two competing parts (referred to as 'G-2'), still others look at the trends in technical progress and are discussing globalization of the fourth generation ('G-4') and the resulting consequences of the overall introduction of the digital economy, artificial intelligence (AI) and of the birth of a new type of technocracy.

Since ages, the increase in trade has been the best recipe for the fly wheeling of economic activity in countries, regions and in the world. In the second half of the 20th century, this prescription was supplemented by the desired multilateral dimension of trade. However, the international institutions in which high hopes were once placed have failed. The World Trade Organization (WTO), the successor of General Agreement on Tariffs and Trade (GATT) has been paralysed for quite some time by a clash of differences in interests by the particular groups of countries, their own structural problems and, more recently, by actions of the USA to block the selection of key dispute judges. Originally the GATT, and later the WTO, were to introduce new states into an organization that was something like a 'club of civilized trading countries' and partners, which were supposed to carry out 'predictable,' rule-based trade that respected wellknown and relatively stable principles.

While the USA has had some success in the disputes placed with the WTO (e.g. the EU subsidies for the Airbus and a number of complicated disputes with China), President Trump has never had much confidence in the WTO. Many experts say that the USA has practically returned to its style of action from the GATT era, when America used to act as a kind of a 'policeman' (a notion used in the conservative The Economist) in international trade de facto settling major disputes on its own. President Trump has declared on many occasions his lack of approval for the WTO decision-making process and for its enforcement. He preferred to decide about the appropriate retaliatory measures on his own, especially if the relations - in his opinion - may be considered 'not fair.' In particular, he tends to take some China - US trade issues literally in his own hands. ${ }^{5}$

From the ideas of liberal, multilateral trade has not been much left outside of the EU. Currently, we have been operating within a myriad of detailed (and mainly bilateral) agreements on trade. Large intercontinental agreements have stalled in their negotiations or in discussions regarding implementation details. After years of preparations and negotiations, the integration agreement of the Pacific region - promoted by the US and Japan, however completely bypassing

\footnotetext{
${ }^{4}$ The Economist, January 26, 2019.
}

${ }^{5}$ The Economist, May 18, 2019 and November 30, 2019. 
China, the leading regional player - was eventually not implemented in its original shape as President Trump withdrew the USA support.

The US - China trade war continued in a tit-for-tat style at various stages of negotiations and is becoming more and more difficult to track (The Economist 2019a). In January 2020, another agreement to reconcile the confrontation was announced. The US would eventually abandon the introduction of new, increased duties on certain Chinese products and lower some already existing rates, while at the same time the Chinese side has committed itself to increased purchases of American agricultural products. This was, however, a never-ending story of negotiations in the same style, as immediately after announcing the deal, the US side added that this was only a 'phase one' of the final agreement.

The 'phase two,' which has been demanded for a long time by the US and which the Chinese side has still been working on, aims at deeper systemic changes in existing trade mechanisms on the Chinese side in order to 'level the playing field' (The Economist 2019b) for honest business competition (among others at the level of the exchange rate mechanism, rules of subsidization, public tenders and investments). This, according to the American side, should help create a more balanced business rivalry, usually referred to as a 'fair game.' All in all, with major differences in economic interests and in the perception of realities, such negotiations in a tug-ofwar style could last practically forever.

Some analysts claim that the pandemic has been in fact a 'nail in the coffin' for the globalization process. The rhetoric and some noticeable symptoms may be considered attractive. Experts estimate (Euronews, May 28, 2020) that about one third of the EU investment projects have been pushed back by the pandemic and Europe is facing enormous challenges in this field. The COVID-19 pandemic is estimated to have increased Internet traffic by an average of around $30-40 \%$.

The problem is, however, probably much more complicated. The globalization processes that started will be progressing anyway, like it or not. A global approach in thinking and forming economic concept of development for particular countries and business will be an overriding consideration in a foreseeable future. The rate at which globalization may progress will differ from region to region, as will the details regarding particular sectors of economy, but the process will be very difficult to be put suddenly on halt. However, it may justify even more the calls for some corrections in the globalization course and even demands for a new type of globalization with more than before affirmative action for the developing/emerging economies. China's position and calls for still not fully explained globalization of a 'new type,' especially in the context of the Belt and Road Initiative, could become stronger.

\section{THE CHINESE FACTOR}

China and the US are the two largest economies, with shares of world GDP, expressed in Purchasing Power Standards (PPS) of 16.4\% and 16.3\% respectively. The EU (with 27 Member States - after February 1, 2020, the UK is not included in the EU statistics) represented a similar size of $16.0 \%$ (the three together accounted for about a half of the world economy). While the US and China are about the same size in terms of total GDP in PPS, however, their respective 
GDP per capita in PPS differs by a factor of about four: USA $=140$; $\mathrm{EU}^{6}=100$; World $=39$; China $=33$.

Since introduction of reforms by Deng Xiaoping in 1978, China has been gradually emerging - quantitatively and qualitatively - as a completely new, difficult to define component of the world economy (Godement 2016; Hübner 2016; Kolodko 2018). The 'new' China somehow automatically disrupted the old order of things and the whole routine associated with it. The Chinese issue quickly proved to be a rather complex problem (Szymański 2019; Fukuyama 2020) - both in intellectual terms and in the very practice of economic life (Kynge 2016). It was not only necessary to come to terms with China's new role in the world and to integrate China into an existing global interdependence system, but it was also necessary to accept (which in practice proved sometimes even more difficult) the current aspirations of the new superpower and its society (Hübner 2016).

It seems that the current, fundamentally interdependent, global system that should be taken into account here, is a multilateral and hierarchical arrangement. At the very top of this complicated structure, it has several critically important 'nodes' of bilateral and multilateral economic and political relations. The four are discussed in an article by Hübner et al. (2018): the US, China, the EU and the Russian Federation. Each of them has also its own military position in the world - individual, or as a member of broader treaties. At present, each of the 3 key 'nodes' (the US, the EU and the Russian Federation) has some specific relations also with China, which are becoming of special and growing importance. As a result, a complex, multidirectional stream of vectors of specific individual interests and interdependence is emerging, which should be taken into consideration when discussing contemporary political and economic relations in the world and the role of "the Chinese factor."

This year, 2020, is the 42nd year since Deng Xiaoping introduced reforms in China (Góralczyk 2018). It is widely believed that China has become - already at the end of the 20th century - the world's champion in using the world's processes of classical globalization for the purpose of own development. ${ }^{8}$ But the story does not end there. After realizing the initial success, China has also gradually become aware of its own limitations (both on the supply and demand side) which will only increase over time, parallel to the growing potential and the levels of production. The strategy may have required some adjustments; however, one could also look for some new opportunities in future. Over time, aspirations of China have been growing and a new strategy has gradually developed. At some point China has found a leader to implement an ambitious plan. President-elect Xi declared in 2013 his intention to resurrect the tradition of the historical Silk Road - a mechanism of most famous trade route in the history of the mankind that connected both ends of the Eurasian super continent for more than 17 centuries. The tradition became main inspiration and the key symbol crucial to the launching of the 'Belt and Road Initiative' (BRI) project (Amighini 2017).

\footnotetext{
${ }^{6}$ For 27 member states after February 1, 2020.
}

${ }^{7}$ Though already very complex, the resulting image remains still simplified when verified with the real life. In fact, the official political and economic attitude of the country in question, vis-à-vis its partners although seemingly uniform outside, also has its own complex and time-changing internal structure.

${ }^{8}$ Compare the remarks on the evolution of globalization processes by Z. Madej (Kolejna korekta, czy koniec globalizacji? Next correction of the course, or the end of globalization?) unpublished manuscript for the Economic Institute of the Polish Academy of Sciences (PAN), January 2020. 
This unprecedented, ${ }^{9}$ still sprawling and open for newcomers, mega-project (Szczudlik 2016) should be seen, as already mentioned before, on the one side - as an attempt by China to address its own problems and development constraints, and as an initiative aimed at applying a new recipe for success at a more advanced stage of globalization - on the other. Modern China wanted to seal their past success in production and trade (achieved still under mechanisms of 'traditional' globalization) by a gigantic, global project of a new type. According to the Chinese initial declarations, it is intended to co-create a new strategic infrastructure for transport and trade in the win-win style and to implement a whole range of other detailed subprojects scattered around the world.

BRI is becoming a central tool for China to actively shape current and future globalization processes. This globalization of the new type, drawing on the possibilities created by the newly launched mega-project, can be considered as a new form of approach to globalization, in general, and perhaps even deserves to be called 'the globalization with Chinese characteristics.'

The size of the whole project is gigantic, its scope is truly global, and the project timespan is expected to reach the mid-21st century, so it could help celebrate the 100th anniversary of the creation of the PRC. The BRI reflects the aspirations of the newly emerging superpower - a candidate for a place at the key table of the world configuration. A decade after the 2008 financial collapse, we witnessed an attempt to create an important, new element of its architecture. However, the Chinese initiative came to be implemented in difficult conditions - at a time when the world was looking for a new long-term balance. The global nature of the project meant that China's modern hybrid economy, which uses both market mechanisms and central decision tools, had to work with a large variety of national economies representing very diverse economic and political systems.

The geopolitical dimension of the BRI project automatically followed the economic impact. From the very beginning, President Xi Jinping (2018) referred to China's Asian partners as a 'community of common destiny,' adding slightly later a new thread of thought on adjusting, or rather 'supplementing' of the existing world order, albeit without an intention of its thorough revision. Now, we are witnessing how this project is transforming into a global, flexible economic initiative that does not have a single, clear definition, rigid operating rules, or an official list of participating countries. Theoretically and declaratively (by the Chinese side), virtually any country that recognizes the principles of peaceful economic cooperation can join it. However, the project does not serve and cannot be used to fulfil individual, especially internal, political goals.

Each case of intention to join the BRI is considered individually and separately with a varying and flexible procedures of mixed political and business feasibility study character. The expected benefits for the parties involved are being considered and assessed. Each individual sub-project is intended to bring mutual economic benefits (the win-win principle), however may have varying from case to case detailed financial parameters - from hard commercial financing to softer requirements.

It has become increasingly clear over time that the intention of the Chinese side is not a modern reconstruction of the powerful, historical mechanism of trade, but rather the creation of

\footnotetext{
${ }^{9}$ Though for some, reminiscent of the ideas of the post-war Marshall Plan - even with fierce protests for such a comparison by the Chinese side.
} 
conditions conducive to the emergence of new ties, both economic and non-economic, between modern China and the rest of the world. The Chinese recipe for transforming globalization and forming its new stage, of which one can make an immediate use.

There are some visible analogies with the mechanism of the old, historical Silk Road, which was a common achievement of the societies of antiquity and the Middle Ages (Liu 2010). The Silk Road mechanism of trade connected oases and large cities along the route, connected Europe with Asia and bonded the various components of the region. Over the centuries, the Silk Road demonstrated the power of economic mechanisms (especially the power of trade) and demonstrated the importance of accompanying cultural interaction forming and transforming our civilization. The resulting 'cultural melting pot' had shaped the key vectors of civilization in which we now live. The historic Silk Road has therefore become a powerful symbol of development through peaceful economic cooperation - a symbol of an idealistic, alternative path to our history based in fact mainly on violence, permanent wars and conquests.

With regard to the historical Silk Road, the very course of this commercial route - from which point to which, through which cities and oasis, what were the main routes, what branches and their reach - have been often fervently discussed. However, the contemporary American historian, Christopher Beckwith, is one of those who try to shift the understanding of the essence of the Silk Road mechanism from the romantic legend of merchants and travellers on camels (resulting in a simplified image of wandering caravans in a desert), to the very essence of this mechanism - the way of functioning of historical communities, in which, and above all, the leading role of trade may have been noticed.

The historical Silk Road that connected key oases and later - Eurasian major cities, and generally East with the West, was confirming the key direction of people's migration, the flows of trade in goods and worked towards integration of the super continent. Most of the societies of antiquity and the Middle Ages were functioning according to the similar pattern, of which the Silk Road was the outstanding and pure example. Beckwith (2009) points out that even clashes between nomadic and sedentary tribes did not, as a rule, take place if both sides could exchange goods without greater hindrances. Tensions, on the other hand, arose when local authorities imposed bans or substantial restrictions on trade. The trade mechanism was common, which is why most modern researchers tend to talk about the Silk Roads in plural, or trade routes in general, rather than about just one such huge phenomenon.

With all the importance and attention paid to the individual subprojects of the modern Belt and Road Initiative - the corridors envisaged, or planned hubs for commerce and super modern transportation lines, the most important, however, is a new, holistic concept of globalization, which we may even call here the globalization with the Chinese characteristics. It is no longer the usage of the existing mechanisms of the West, it is rather an attempt to actively create own reality on an ongoing basis. Ultimately, China could be aiming to lay the foundations for a new, revised global order in the world, although, paradoxically, the one that has been present, opened for China the way to the very top.

The Chinese recipe for success in the current conditions of a further changing and globalizing world is therefore two-prong: on the one hand, it is based (continuation of the old strategy line) on the creation of conditions for the formation and support for the large world-class enterprises (such as, e.g., the Huawei Technologies, or the Alibaba Group) capable of competing on a global scale with the strongest foreign rival. On the other hand - we are witnessing a creation of new "global" facts - building own footholds for trade and transport on a global scale 
(such as construction, together with foreign partners, of strategically important railway lines and new road networks, seaports and hubs, as well as cooperation on a global scale on a variety of other projects). Ultimately this could only mean a gradual economic expansion in the world and a broadening of the sphere of soft influence with repeated declarations (however, very difficult to implement under current realities) of political neutrality and of not engaging in internal matters or conflicts of particular countries.

Particular subjects were supposed not only to automatically see local phenomena in a global context, or easily buy and sell on a planet-wide scale (and especially according to the Chinese experts and the spirit of the BRI also directly build necessary infrastructure for that), but the Chinese side was talking lauder and lauder about the need for a 'new globalization. ${ }^{10}$ The thinking of this type contains some elements of the cultural specificity of each country, but at the same time requires an extraordinary coordination effort on a scale that only the largest international organizations of the world have attempted to take up so far. This requires, e.g., a theoretical and practical knowledge of the cultural characteristics of the partner countries as well as an extremely efficient decision-making and logistics mechanism, not to mention the basic economic efficiency.

We, therefore, have another example of the hybrid approach in the Chinese economic model. At one end, we have a solid trust in global competition - the selection and allocation system based on market mechanism that can guarantee the success of own leading companies (including the faith in their research capacities, creativity and ability to innovate, as in the case of research on the latest -5G- version of Internet, or on the application of AI). On the other end, however, we notice a strong belief and conviction that all this should be done parallel to a creation of concrete and tangible, rather traditional (though top-notch according to the present technical standards) facts of life, like building and developing a specific, state-of-the-art infrastructure for the world transportation system and trade: railway lines and large hubs for logistics purposes.

In the context of the competition at the very top, there is a recurrent talk now of the 'decoupling' or disengagement process (China with the US, and with the West as a whole). This idea, as a part of a future vision, is being mentioned more and more often, although earlier and until recently, it seemed that there would be no problem and that both sides could function perfectly side by side. The 'decoupling' - suggested and often directly recommended strategy for the West (Fukuyama 2020) - could be seen as a reaction by a large group of countries on how much they were, in the difficult times of the pandemic, dependent on a single country like China. On the other hand and at the same time, some circles of intellectuals, politicians, or academia started speculating that it was also possible to move away from the 'American-led world order' and the 'American values' (even if the concept itself has become less and less precise) to a new, little defined configuration and arrangement.

Different from the times of the past Cold War, when the world was also cracked these into two (though other) fiercely competing parts, the Western side, is far from a monolith now. Attempts to create a single group of countries in opposition to China are not so easy. Perhaps it may be easier to convince Australia for such a move, or even Canada, but Europe, which has now become a kind of a thumb on the scale in the world configuration, has been facing some

${ }^{10}$ See, e.g. studies by the Chinese government for the 2019 Boao Forum for Asia. 
serious internal problems (including the issue of the 're-inventing' itself, which has been demanded from many sides), as well as those related to the pandemic, ${ }^{11}$ and is struggling on many external fronts including the conceptual one - the finding of a fresh formula for the transatlantic alliance. Josep Borell - the EU Foreign Policy Chief - in an interview with Euronews in mid-May 2020, was asked - in view that President Trump does not have confidence in China, does he himself have it? In his response, Borell revealed the EU's multifaceted attitude towards China: from the EU's point of view, China is no longer only a strategic rival (which label was officially given to China in the EU relatively recently), but also a country offering cooperation, a competitor and a rival at the same time.

So, could China realistically become a candidate for a world leader? How is it dealing with traditional weaknesses of the highly centralized system? Being under a pressure of the waves of social unrest and of the demands for deep changes, as well as the pressure of a rivalry regarding various types of spending, including military ones, the USSR and its camp did not meet the challenge in the 2 nd half of the XX century. Kai-Fu Lee (2018) makes it clear that in China, a centralized and potentially bureaucratic system has not destroyed Chinese propensity to innovation and to accept most recent innovations (Chinese-specific, early, massive use of mobile phones even through the little-educated layers of the society; similarly the massive, rapid spread of functioning in society based on the use of the On-line-2-Off-line system and QR code readers).

Serious sources give us an up-to-date and detailed overview ${ }^{12}$ of China - US technological rivalry (or rather China-rest of the world). It analyses the areas in which China has gained an advantage for now and tomorrow (super-fast rail, drones and nuclear power plants). For example, China never mastered the perfect technology of producing an internal combustionengine car, but it was successful in developing the production of electric vehicles. Weltmeister, Nio and others will be competing with Tesla and VW. It shows areas where struggles continue, such as the microprocessor area and those where China's serious advantages, such as in some areas of AI, are already expected.

Often the crux of an accelerated Chinese success was in application of a complex, rapid routine from the beginning to an end, from the generation of new idea to its implementation. It started with the initial decision on how to reach the required technology (in different ways: completely commercially and legally, in a somewhat forced manner on the commercial partner, as well as through approaches not entirely acceptable). It moved immediately to the stage of adapting the product to their own needs and adding their own intellectual thought, and finally, also without delay - to mass production of such an advanced product. In the classical market economy and traditional Western democracy, this is a difficult and long process - in the centrally led Chinese economy, these processes can be significantly shortened, as a uniform decision-making criterion may be applied in the decision-making process at all levels of the economic structure. From the point of view of the West and especially the US, however, China has been increasingly perceiving as a rival and the case of 'high-tech authoritarianism' - a

\footnotetext{
${ }^{11}$ A major weapon in combating the current crisis should be the package of 750 bn Euro of grants and loans announced by the Head of the EU Commission, Ursula von d. Leyen, on May 27, 2020, often compared to, and labelled as the European Marshall Plan.

${ }^{12}$ E.g. The Quarterly Technology Supplement to The Economist, January 4, 2020.
} 
'country that is spreading and can function over a huge political space': from ability to promote development of companies - world leaders in AI to hard line approach in areas considered as sensitive for national strategy.

For the first time, the success of a centrally-led national economy is emerging on this scale. It seems that the classic, long-uncultivated model discussion on system efficiency with new computing, data collection and AI technology may return. ${ }^{13}$ Chinese advantages in this and in previous stages of catching up demonstrate the importance of compliance, even if sometimes to some extent (formally and informally) forced, decision-making criteria at the national and business level.

There is undoubtedly the issue of the political and social system, which can be considered democratic. At this point, the Western literature refers to the concept of 'input legitimacy' (people vote democratically for what they want, and even if it's not the optimal, it follows a democratic procedure), and 'output legitimacy' (giving people what they want, but assuming that those who ultimately decide know better).

\section{THE PANDEMIC FACTOR}

At the turn of 2019 and 2020, we witnessed to a new type of economic super-shock ${ }^{14}$ of global proportions - an outburst of pandemic that started in Chinese Wuhan just before the Western and - when more details emerged and the transmission human-to human became known - the Chinese New Year. ${ }^{15}$ This new kind of terrible global disaster was caused by a new, or a mutation of already existing coronavirus, or SARS-Cov-2.

The virus was first discovered in China. Due to the rapid spread of the disease including mortality rate increase, some sensitive hubs of modern civilization with intensive interaction among people, as well as industrial, trade and tourist centres, were brought to a standstill. Many national borders were re-established, new cultural patterns of social behaviour started emerging along the lines of social distancing up to temporary lockdowns of individual citizens. This could

\footnotetext{
${ }^{13}$ On the sidelines of big discussions and large disputes about fundamental issues - such as on the basic economic model, along the lines of the market economy vs. centrally planned - the old questions and dilemmas are put under new light. Until now, the nebula of individual and detailed economic decisions, despite their many flaws (many of which could be now avoided) was ultimately more efficient and gave better results than the centrally decided ones, based on poor information, rigid and often delayed. It was a historic triumph of the market economy and a failure of the hopes of great economists-mathematicians such as Leonid Kantorovich in the Soviet Union or Oskar Lange in Poland. Their historical discussions with Mises and von Hayek are recalled now yet again. The use of linear programming and dual prices proved once to be a theoretical construction without a practical application, but what about the new era of AI and completely new systems for collecting and processing information?

${ }^{14}$ Usually unpredictable, or very difficult to predict, factors such as major natural disasters could dramatically change the path of growth of national economies, their components or even whole regions - all proportionately to the scope of interrelation and interdependence in the segment of the world concerned.

${ }^{15}$ The outburst of the pandemic - according to the Chinese Government version - can be traced down to December 27, 2019, when Dr. Zhang Jixian, the Head of the Respiratory Diseases and Intensive Care Department of the Traditional Chinese and Western Medicine Hospital in Hubei Province, reported three cases of pneumonia of unknown cause, immediately after examining the patients. This was the first report by the Chinese local authorities on suspicion of the emergence of a new disease.
} 
create the 'new normal' trend, of new behaviour and new, long-term cultural patterns, different in each community but with some clearly noticeable common denominator.

The impact, in our opinion, is not through the actual scope of the infections and fatalities this is often within the normal seasonal flu and other diseases. It is rather through the psychological working (necessity of self-isolation, constraints on free movements, the nature of risks - invisible, hidden virus ready to attack everywhere) - a new unknown earlier feeling to most of people and then - the economic consequences of isolation that bring many operations to a standstill.

Has the pandemic outburst created a new situation - can we talk about the simultaneous cooperation and rivalry before the pandemic as one reality which changes now to a different one? What is the message from this change of scenery for China and what is the message for the West?

Predictions for 2020-2021 show, after initial decline, a reasonably strong performance of national economies of China and India (GDP rate of growth in the range of $1-2 \%$ in $2020,{ }^{16}$ as contrasted with negative growth in the richest economies of the West and the whole world, and the rates of $9-7 \%$ for the two countries in 2021 (WEO 2020)).

Looking at the developing trends, it seemed sometimes to many of us that the time has come for great potential political and cultural breakthroughs in the world, however, the immediate reaction to the pandemic has been full of old, traditional reflex - mainly to isolate itself within national borders. General lack of leaders adequate to current needs more and more countries face major challenges in their upcoming fundamental political and economic choices. There are chances for further positive changes on a global scale, but at the same time the societies of many important world players, as rarely when, are divided into two opposite camps of almost equal parts, like those in the US, the UK, or even Poland and the Czech Republic.

Perhaps the long-haul effect of current dramatic situation will be more noble and bring impulses to new processes and institutions. The role of the UN (at the top) has been difficult to notice. The WHO, and its professional leadership, have passed the difficult test so far, much better. It seemed that the EU initially gave up the fight (by 'walkover' - to use the forging of the Polish Nobel prize winner in the field of literature - Olga Tokarczuk (2020)) and only later after the initial, most sensitive phase - mobilized iteself to make up for the delays in early reaction.

The final effect of the coronavirus epidemic is unknown at the moment. It is not even known what is the time horizon we have to think about. Scenarios can be extremely different because the problem is unprecedented. In the short-term, extreme losses are becoming almost obvious for individual countries, regions and around the world, or also individual industries that are clearly related to the movement of people - such as tourism, the vivacity. In the future, however, 'destructive' global links may also be revealed in less obvious areas at first glance, but also new business opportunities for less-seen areas.

So far, the IMF predicts that as a result of the pandemic a major economic crisis ('The Great Lockdown' of 2020) may be triggered, the biggest since the Great Depression with overall drop

\footnotetext{
${ }^{16}$ Recently published data by the China's National Bureau of Statistics (initial estimates as of July 16, 2020) indicate that in the first half of 2020, China's economy has indeed gradually moved from the slowing down to recovery and moderate growth. At comparable prices, country's GDP fell by 6.8 percent (year-on-year) in the first quarter, however already grew by 3.2 percent in the second quarter of the year.
} 
in GDP in the order of minus 3\%. To compare the losses of the global financial and economic crisis of 2009 was about minus $0.1 \%$ of the GDP (WEO 2020).

As a result of all uncertainties and of the changing position of the US vis-a-vis China, there may be a change in the existing pre-pandemic world supply chains: Chinese supplies are being replaced by Taiwan, South Korean companies and by a stronger position of India (Govindarajan - Bagla 2020). While the US companies are looking for alternatives to China, India becomes a natural destination. India have an English speaking, highly skilled workforce, the cost of labour is still relatively cheap and more important it is a growing huge market of 1.3 billion people whose disposable income is growing. Companies in the US, Canada, Europe and Australia have been hit with supply chain shocks as the flow of materials from China was disrupted by the pandemic. CEOs are confidentially asking their supply chain teams to develop additional sources that are completely independent of China.

There may be a further departure from the purchase of products in the traditional way in favour of online shopping. Companies offering product and service supplies for diverse individual customer needs can spend a period of special prosperity. There may be completely new, innovative types of services on the market. Companies, not providing the supply of products and services to private addresses, may have trouble staying in the market.

Excessive dependence on one producer, or one supply source can, in the future, strengthen the trends for a new kind of thinking, where the starting point of each strategy will be automatically the diversification aspect. More than 20 years ago, electronics companies from Taiwan led the way into mainland China, but now in the wake of COVID-19 more and more leading business leaders claim that 'the global industrial chain will reduce its dependence on China.' ${ }^{\text {'17 }}$

Stock markets, showing chaotic declines and their compensation at the beginning - in the longterm, until there are signs of a return to old activity or rivalry already in the new world - have been expected to suffer huge losses in the atmosphere of uncertainty, or in the face of pessimism about the future ${ }^{18}$ detailed negative signals, an example of what could be the fall in oil prices.

The approach to epidemic threats has been and is varied across countries, although a common denominator can be seen, at least in the declarative layer. Some countries, even the rich, face elementary problems in combating the epidemic, and the world as a whole is astonishingly unprepared for such a disaster. There is no clear pre-emitting, proactive and centrally coordinated action in the EU. Common initiatives are sort of on the margins. The virus attack is used to insulate and take protective measures within individual national economies and even within smaller regions (Lombardy, Italy) or individual agglomerations.

In addition to the opinions routinely criticizing China for a belated response at the first symptoms of the epidemic, however, some exceptions are those of international organizations. The WHO report of 28 February 2020 is precisely an example of an international assessment that essentially praises China for using an appropriate combination of traditional coercive methods together with high-tech technologies for the precise implementation of the quarantine rules introduced on an unprecedented scale.

\footnotetext{
${ }^{17}$ Such as a billionaire Cao Dewang, of Fuyao Glass Industry - reported by Bloomberg TV in March 2020.

${ }^{18}$ In August 2020 they managed however to largely make up for the previous losses, which shows how the new reality of the pandemic-shaped world economy became full of new reactions and will require a further reflection and analysis.
} 
At the same time, the western media provided, in the initial phase of the pandemic outburst, only three positive examples of the fight against the virus: Singapore, South Korea, and Taiwan, which are more democratic than China. The success of South Korea, which had the highest number of infections outside China for a while, is attributed to the technical backroom that the government had at the right time (mass conduct of a huge number of tests), its competence, as well as trust - public support for the government in the related projects. In Singapore, success was attributed to good organization and the relevant state-of-the-art technique, which has allowed to accurately trace the contacts and movements of people infected with the virus.

Paradoxically, according to many experts, the first American response resembled a rather little transparent early Chinese reaction (immediately referred to in the Western media as the Chinese 'new Chernobyl'), where the administration seemed to minimize the threat assessment and even drown out the voices of the so-called whistle blowers. Only the subsequent, the coordinated response of local administrations is trying to make up for these losses and forgiven opportunities.

A rather frustrating result of the pandemic and related political processes generated could be some longer-term changes in cultural attitudes among various world communities. Mainly as a result of America's changes of relationship with China, the societies' attitudes may undergo permanent transformation. In April 2020, a Pew Center survey found that two-thirds of the Americans say they have an 'unfavorable' view of China, which was the most negative rating for the country since the Center began asking the question in 2005.

\section{HOWEVER, THE FUTURE DEPENDS FURTHER ON ALL OF US}

With all these old and new dilemmas, the overall end-result of the pandemic is unknown and rather difficult to predict. Future scenarios can vary a lot and within that - they still may not be uniform for individual countries, or within continents and regions. In a short-term, very significant losses are becoming obvious. Individual industries related to the movement of people such as, e.g., tourism, hospitality or aviation have been suffering most. In more distant future, however, some 'destructive' global links and relations in less obvious areas may also be revealed.

The pandemic has become some sort of a brutal test that exposes many weaknesses in our life we did not realize, but also those we kind of knew about, but somehow neglected to take care of adequately in view of the effort and cost involved. Such 'test' by the pandemic helped identify them in a harsh way and triggered thinking on possible improvements in the manner we organize our life and on the functioning of essential institutions of our life.

In our opinion, the post-pandemic economic cooperation is likely to face new constraints and to be narrowed down on the international level and on the global scale. The main reason for that would be mainly a new level of awareness of national security concerns. Economic cooperation would have perhaps a better chance of developing primarily under existing formal integration groups and under solid, often bilateral trade agreements. Of course, there would be always some exceptions to this general new tendency, as the search for special opportunities will continue according to the general logic of the market economy system. For quite some time the Trump administration have been referring to the virus as the 'Chinese,' or 'Wuhan' virus. ${ }^{19}$ In the background, of course, we have presidential elections in the US at the end of 2020.

\footnotetext{
${ }^{19}$ The Chinese side notices that the fact that Wuhan was the first to report the problem of the epidemic does not mean that it is its source. The Chinese side stresses until now that the origin of the new coronavirus has not been confirmed.
} 
In general, President Trump's rhetoric on Beijing turned increasingly aggressive as the coronavirus outbreak worsened in the US. Mid-May this year, the Commerce Department tightened the rules of supplying e.g. Huawei Technologies with chips and other parts by not only American, but also e.g. Taiwanese companies without a special licence. It was administration's first major economic measure against China after the two countries came to some sort of agreement in January 2020.

As many others, Kai-Fu Lee predicts in his book (2018), that the future rivalry between China and the US will largely take place in the area of AI research and its application. He also notices that an unclear possibility of a major breakthrough in such research is the source of a particularly large measure of uncertainty regarding future, as it can set further directions for the technical progress in general. He adds, however, that the current era is not an era of great classical breakthroughs like the historical achievements (the steam engine, electricity, or radio) based on the foundations of physics, neither the work on the first A-bomb. ${ }^{20}$ This is rather an era of specific applications of the AI and of introduction of further improvements in the detailed algorithms used - the era of small improvements (by smaller format inventors of 'DIYs ${ }^{21}$ type, as he puts it). However, a new chip especially designed for AI purposes may still become a subject of fierce competition. Otherwise, if no major breakthrough in an unexpected direction happens, then, as Kai-Fu Lee predicts, in about 5-6 years, China may have an opening to become the leader in this field.

Some studies and reports, e.g. Mc Kinsey Global Institute (2019), prove that the world depends already more on China, not the other way around. Chinese reforms were, in their early stages, a source of some significant benefits also for the outside world. Among other things, they resulted in lower world market prices for the consumer. Companies around the world have discovered new business opportunities and, in general, the dynamics and scale of the Chinese market. However, these changes had also their specific cost, connected with job losses for the middle class, particularly in the rich Western countries.

However, taking into consideration the additional factor of the pandemic and in the context of the rise of the protectionist tendencies and increasingly strong geopolitical emotions we may witness an overriding new trend of the weakening of China ties with the external world. As a result of recent development, a search for substitute producers for those blacklisted by the US has been rapidly developing. We have had here numerous new cases of cooperation where Japanese and Taiwanese companies replaced as partners the Chinese ones. We have had major structural changes in the sources of supply for key Chinese companies, too. On the other hand, the strengthening of the Sino-Russian cooperation in strategic areas, including the defence sector, has been also clearly visible.

In most of the past and current assessments, the unusual style of dealing with international trade issues (especially between the US and China) by President Trump, who is accustomed mainly to business-type negotiations, is highlighted. However, it seems that the whole thing is not about the personal style of negotiations and the game of concessions, although they attracted broad attention in the past. It is more about the key fundamental and long-term structural issues. It is rather a clash of different general concepts in such basic notions as freedom, civil

\footnotetext{
${ }^{20}$ Potentially, according to Lee, this could be, for example, a new type of the so-called 'deep learning.'

21 "Do It Yourself" type.
} 
rights or governance by the elites of the two countries (and eventually a sober calculation what is to lose or gain by a possible change in the world leadership). Actually, the personality of the key leader, apart from the extreme situations, should be seen as a rather secondary consideration. The most essential decision is produced nowadays rarely by single individuals with strong personalities. For example, even with a potential change of the leadership in the US - looking at the to-date activities and declarations - it doesn't seem that the trade negotiations between China and the US under the leadership of the current US opposition could have been easier for the Chinese side.

Today, although in fact only relatively recently, the world generally recognizes China's potential and top-ranking places in the field of innovation (Shahid - Piątkowski 2019), technical progress and scientific research. ${ }^{22}$ In a climate of fierce rivalry, the awareness of China's place and leading role at the very top of the global hierarchy and purely economic comparisons based on hard facts, have been accompanied recently by reflections of more subjective social and political nature. Now, many 'Western' doubts have come down to the questions on how the achieved huge economic and scientific potential is used by a political system different from the Western type democracy and how the fruits of the economic success are ultimately shared within the society?

On the world scene, the competing sides struggle with each other by using mainly soft tools of influence (e.g. sophisticated propaganda delivered via variety of information channels), however, from time to time also hint to remind about their political and even military potential. The processes of classical competition or economic expansion is becoming increasingly politicized.

All in all, the present extremely complicated, multidimensional situation including the vectors of rivalry, but above all, the imperative of cooperation requires bold moves and solutions - decisions taken not on a unilateral basis but solutions agreed at the very top among all key superpowers. This would be an unprecedented approach for today's standards, but the scale of the task is also unprecedented. Kai-Fu Lee, with unique insights in super-modern technologies that will most probably shape the future, indicates the pointlessness of such a rivalry in the face of the vastness of a completely new quality of our life in future and future technologies, which can create practically a never-ending variety of applications of AI, even in areas which we can already identify from today's perspective. At the same time, the winning of the rivalry becomes for each side (even without major declarations, consciously or subconsciously and not only for the leaders, but also for the significant parts of each society) a certain obsession and means a classical defeating of the other side.

We have reached a point, however, where the rivalry, if it is not to end with something other than an ultimate disaster, requires an agreement between the competing parties and a mutual belief that the partner's success can also be everyone's interest. This calls for a new level of trust, excellent communication and ability to set common goals. In this case, China faces a fundamental challenge of convincing other world superpowers that their new vision of globalization (including the BRI) can be implemented on the basis of its new global openness and fair-style competition.

\footnotetext{
${ }^{22}$ Even without immediate, direct and practical application, such as the research in the so-called Dark Matter.
} 
Can China open a new chapter in the history of globalization, which rejects traditional geopolitical confrontation? The model of globalization with the restoration of the tradition of the Silk Road is as noble and beautiful for the intentions and assumptions, as is difficult to achieve in an era of uncertainty, ever-present but hidden rivalry and the complexity of the modern world. Each stumble is closely observed and exposed by the western mass media and in the huge watching analytical research machine (De Jong et al. 2017)

As for the BRI itself, China must overcome both some major 'external' challenges - despite all existing barriers achieve effective cooperation with a wide range of culturally, politically and economically diverse partners - each having own detailed specifics. On the other hand, China must meet also the systemic 'internal' challenges - be able to adjust to the universal requirements of high economic efficiency and of adequate financing of the whole operation. If the concept is to succeed, the specific economic system of modern China needs to adapt accordingly, and large companies in the state sector, or close to it, must learn to interact effectively with much smaller companies such as in e.g. Uzbekistan, or in traditionally market-based Pakistan. In Annex 2, we present an overview, based on the report by Nikkei International (2018), of problems encountered by particular individual projects of the BRI. A Chinese global approach in the strategy is clearly visible here and the scope of the problems - not so dramatically big as often portrayed by the Western media, but also not as ideal and smoothly implemented as the Chinese side would like to see it.

Can China eventually become, ${ }^{23}$ as several Chinese experts declare, a 'new type of emerging superpower' and open a 'new era'? Can the results of the launch of the BRI remain only an acceptable complement to the already existing world order without being considered by the world community as an attempt aiming at its thorough revision?

There are sometimes striking similarities, especially when adjusted for cultural differences, in the behaviour of the two competing rivals, though China has to (almost 'by definition') make a greater effort in explaining its - overshadowed by the location of the virus discovery - position. Rivalry between two partners who eventually complement each and act as the Siamese brothers has been a strange enough phenomenon for quite some time in the pre-pandemic realities, but there is still the issue of the political leadership.

China has one of the world's longest continuous histories as a society, and there are a number of continuities between its different dynasties and the present (Fukuyama 2020). Chinese statehood longevity and greatness of the culture are obvious and, according to the Chinese side, should be fully recognized and accepted by everyone, also, self-explanatory and obvious. China has long hesitated before taking some serious global responsibility. Even recently, however admittedly in very difficult times of the pandemic for them, when China took over the chair of the Security Council, in April this year, it did not convene any session.

Can China convince its key existing rivals about positive aspects of their new vision of globalization? This is the crux of the matter and these are all key questions in thinking about our common future. One-sided solution by a single superpower is practically impossible now if we do not want to destroy ourselves. We must live together in one planet - with all the existing imperfectness in each major player, who however are willing to discuss the issues and conduct a dialogue.

${ }^{23}$ The dilemmas of this overall vision, in a multidisciplinary and largely innovative way, are illustrated by Harari (2015). 
In the thicket of challenges, we see those for the West, which needs extraordinary wisdom probably not limited to the ability to compete and fight a rival, but rather ability to distinguish between what is unacceptable in trade and investment practices and where a rivalry can work for the good of the whole civilization. The West should not only criticize China for a global expansion via the Belt and Road Initiative mechanism, but needs more of own, original ideas for global competitive projects. By the way, the overcoming of negative economic impact of the pandemic is a very good occasion to launch a new generation of projects of this type.

Unfortunately, the bad outcome of the current developments will be most probably a disengagement process - the West will be trying to lessen the dependence on China which in the times of pandemic become too obvious and too excessive. Relatively easy target may get strong popular support. The world however needs in these times of potentially humongous recession a strong China and a strong West, not sides weakened by mutual attacks that doesn't make sense.

From the western perspective, modern China is certainly not a country of an ideal system, with some structural, difficult problems not being solved for quite some time. However, there is also no guarantee that more democratic in the Western sense and less authoritarian system can handle the Xinjiang Uyghur, or the Hong Kong problems. From the Chinese perspective - the West is probably equally difficult sometimes to understand and approve of in many details.

All in all, there are certainly gigantic challenges here - at all possible levels - for modern China, already a leading economic power and a candidate for the new world leader/co-leader, even in a broader sense. Perhaps the sense of a need for a joint action will increase and may force a global approach to things that we have seen so far only in a local and individual context. A shock and a growing sense of the common burden - as well as the cooperation in overcoming it - can be an anguish and additional ballast for societies but can also dramatically change the point of view necessary for a positive evolution of the world.

\section{REFERENCES}

Amighini, A. (2017): China's Belt and Road: A Game Changer? Italian Institute for International Political Studies (ISPI).

Babones, S. (2016): Russia and the New Silk Road. http://rethinkingrussia.ru/en2016/02/Russia-and-thenew-silk-road/.

Babones, S. (2017): American Tianxia: Chinese Money, American Power and the End of History. Kindle. Beckwith, Ch. (2009): Empires of the Silk Road. Princeton.

China and the World in the New Era (2019): White paper, The State Council Information Office of the PRC. Foreign Languages Press, September.

De Jong, S. - Oosterveld, W. Th. - Roelen, M. - Klacansky, K. - Sileikaite, A. - Siebenga, R. (2017): A Road to Riches or a Road to Ruin? The Geo-economic Implications of China's New Silk Road. Hague: The Hague Centre for Strategic Studies.

Fukuyama, F. (1989): The End of History? The National Interest, No. 16, Summer.

Fukuyama, F. (2020): The China Challenge. What Kind of Regime Does China Have? The American Interest, 15(6): May 18. 
Godement, F. (2016): Czego chca, Chiny? (Whas does China Want?) Warsawa: Wydawnictwo Akademickie Dialog.

Govindarajan, V. - Bagla, G. (2020): As COVID-19 Disrupts Global Supply Chains, will Companies Turn to India? Harvard Business Review, 25 May.

Góralczyk, B. (2018): Wielki Renesans. Chinska transformacja i jej konsekwencje (The Great Renaissance. Chinese transformation and its consequences). Warsawa: Wydawnictwo Akademickie Dialog.

Harari, Y. N. (2015): Homo Deus. Krótka historia jutra (The short story of tomorrow). Krakow: Wydawnictwo Literackie.

Hübner, W. (2016): Nowa rola Chin. Jak jạ zaakceptować? (China's new role. How to accept it?). Wroclaw: Prace naukowe Uniwersytetu we Wrocławiu, No. XXX.

Hübner, W. (2018): Szlak Jedwabny i Chiny (The Silk Road and China). Warsawa: Akademia Finansów i Biznesu Vistula.

Hübner, W. - Rybicka, M. - Wieszczycka, W. (2018): Inicjatywa Pasa i Szlaku - parametry strategii Polski (The Belt and Road Initiative - parameters for Poland's strategy). Kwartalnik Nauk o Przedsiębiorstwie, 4: 34-47. IMF. (2019): Regional Economic Outlook: Asia and Pacific. October.

IMF. (2020): World Economic Outlook: The Great Lockdown. Washington, DC. https://www.imf.org/en/ Publications/WEO/Issues/2020/04/14/weo-april-2020; accessed May 30, 2020.

Kolodko, G. (2018): Czy Chiny zbawią świat? (Will China save the world?) Warsawa: Wydawnictwo Prószyński i S-ka.

Kolodko, G. (2020): After the Calamity: Economics and Politics in the Post-Pandemic World. Polish Sociological Review, 2(210): 137-155.

Kynge, J. (2016): China's Silk Road in Central Asia: Transformative or exploitative? Financial Times, April 27. Lee, K.-F. (2018): AI Superpowers. China, Silicon Valley and the New World Order. Boston - New York: Houghton Mifflin Harcourt.

Liu, X. (2010): The Silk Road in World History (The New Oxford World History). Oxford University Press. McKinsey Global Institute. (2019): China and the World. Inside the Dynamics of a Changing Relationship. Report, July 1.

Petri, P. A. - Zhai, F. (2013): Navigating a Changing World Economy: ASEAN, the People's Republic of China, and India. Asian Development Bank Institute Working Paper Series, No. 404.

Shahid, Y. - Piạtkowski, M. (2019): The Future of Open Innovation: China and the World. The World Bank's Policy Note, December.

Szczudlik, J. (2016): Three Years of the Silk Road: Successes and Challenges. PISM Bulletin, No. 71(921). Szymański, W. (2019): Era autodestrukcji (The auto-destruction era). Warsawa: Diffin.

The Economist. (2018): Slowbalisation. January 26, 2019.

The Economist. (2019a): China and America. A New Kind of Cold War. Special Report, May 18.

The Economist. (2019b): Global Trade. It's the End of the World. ... November 30.

Tokarczuk, O. (2020): Okn (The Window). https://studioopinii.pl/archiwa/197733 02.04.2020.

UNCTAD. (2019): Key Statistics and Trends in Trade Policy 2018. Geneva.

WEO (2020): World Economic Outlook, April 2020: The Great Lockdown. International Monetary Fund https://www.imf.org/en/Publications/WEO/Issues/2020/04/14/weo-april-2020; accessed May 15, 2020.

Xi, J. (2018): Chinskie marzenie (The Chinese dream). Warsawa: Wydawnictwo 'Kto jest kim'. (Access 15 May 2020)

Yamada, G. - Palma, S. (2018): Is China's Belt and Road Working? A Progress Report from Eight Countries. Nikkei Asian Review, March 28, 2018. 


\section{APPENDIX 1}

Table 1A. Key forecast results (at market prices) by 2030 (the baseline scenario)

\begin{tabular}{|l|c|c|c|r|r|r|r|r|c|}
\hline \multirow{2}{*}{} & \multicolumn{5}{|c|}{2010} & \multicolumn{3}{c|}{2030} & \multirow{2}{2}{ 2010-2030 } \\
\cline { 2 - 10 } & Population & GDP & $\begin{array}{c}\text { Share } \\
\text { (the } \\
\text { world) }\end{array}$ & $\begin{array}{c}\text { GDP/ } \\
\text { cap }\end{array}$ & Population & GDP & $\begin{array}{c}\text { Share } \\
\text { (the } \\
\text { world) }\end{array}$ & $\begin{array}{c}\text { GDP/ } \\
\text { Cap }\end{array}$ & $\begin{array}{c}\text { Growth rate } \\
\text { GDP (\%) }\end{array}$ \\
\hline ACI & $3,167.0$ & 8.8 & 14.8 & 2.8 & $3,631.8$ & 33.29 & 27.7 & 9.17 & 6.9 \\
\hline ASEAN & 593.4 & 1.6 & 2.6 & 2.6 & 706.0 & 4.63 & 3.9 & 6.6 & 5.6 \\
\hline PRC & $1,350.0$ & 5.7 & 9.6 & 4.2 & $1,402.3$ & 22.08 & 18.4 & 15.8 & 7.0 \\
\hline India & $1,225.0$ & 1.5 & 2.5 & 1.2 & $1,523.5$ & 6.57 & 5.5 & 4.3 & 7.6 \\
\hline World & $6,641.0$ & 59.33 & 100 & 8.9 & $7,932.8$ & 120.07 & 100 & 15.14 & 3.6 \\
\hline Europe & 511.3 & 17.64 & 29.7 & 34.5 & 527.8 & 26.0 & 21.7 & 49.3 & 2.0 \\
\hline USA & 310.4 & 14.43 & 24.3 & 46.5 & 361.7 & 23.0 & 19.0 & 63.0 & 2.3 \\
\hline
\end{tabular}

Source: Petri - Zhai (2013).

Table 1B. Basic forecast results (purchasing power parity) 2010-2030

\begin{tabular}{|c|c|c|c|c|c|c|c|c|c|}
\hline & \multicolumn{4}{|c|}{2010} & \multicolumn{4}{|c|}{2030} & \multirow{2}{*}{$\begin{array}{c}2010- \\
2030 \\
\text { Growth } \\
\text { rate }(\%)\end{array}$} \\
\hline & Population & GDP & $\begin{array}{l}\text { Share (the } \\
\text { world) }\end{array}$ & $\begin{array}{l}\text { GDP/ } \\
\text { cap }\end{array}$ & Population & GDP & $\begin{array}{l}\text { Share (the } \\
\text { world) }\end{array}$ & $\begin{array}{l}\text { GDP/ } \\
\text { cap }\end{array}$ & \\
\hline $\mathrm{ACl}$ & $3,167.0$ & 15.9 & 24.0 & 5.0 & 3,632 & 61.4 & 39.3 & 16.9 & 7.0 \\
\hline ASEAN & 593.4 & 2.76 & 4.2 & 4.6 & 706.0 & 8.5 & 5.4 & 12.0 & 5.8 \\
\hline PRC & $1,350.0$ & 9.4 & 14.1 & 7.0 & 1,402 & 36.4 & 23.3 & 26.0 & 7.0 \\
\hline India & $1,225.0$ & 3.8 & 5.7 & 3.1 & 1,524 & 16.5 & 10.6 & 10.8 & 7.7 \\
\hline World & 6,641 & 66.3 & 100 & 10.0 & 7,933 & 156.3 & 100 & 19.7 & 4.4 \\
\hline Europe & 511.3 & 14.5 & 21.8 & 28.3 & 527.8 & 21.7 & 13.9 & 41.1 & 2.1 \\
\hline USA & 310.4 & 13.1 & 19.8 & 42.2 & 361.7 & 20.7 & 13.2 & 57.17 & 2.3 \\
\hline
\end{tabular}

Source: Petri - Zhai (2013).

Notes: Population in million; GDP: billions of 2009 dollar; GDP/cap in 2009 dollar. 
Table 2. ACl rates of growth - selected countries/regions of the world (historical and in five-year ranges, since 2010)

\begin{tabular}{|l|c|c|c|c|c|c|c|}
\hline Period & ASEAN & PRC & India & Japan & USA & Europe & World \\
\hline $1990-2010$ & 5.0 & 10.4 & 6.5 & 0.9 & 2.5 & 1.9 & 3.4 \\
\hline $2010-2015$ & 5.7 & 8.7 & 8.7 & 0.8 & 2.3 & 2.1 & 3.6 \\
\hline $2015-2020$ & 5.7 & 7.4 & 7.7 & 1.1 & 2.3 & 2.0 & 3.6 \\
\hline $2020-2025$ & 5.6 & 6.4 & 7.2 & 1.2 & 2.3 & 1.9 & 3.6 \\
\hline $2025-2030$ & 5.3 & 5.5 & 7.0 & 1.2 & 2.3 & 1.8 & 3.5 \\
\hline
\end{tabular}

Source: Petri - Zhai (2013).

\section{APPENDIX 2}

IMPLEMENTATION OF SELECTED PROJECTS UNDER THE BELT AND ROAD INITIATIVE IN EURASIA (AS OF MARCH 2018)

\begin{tabular}{|c|c|c|c|c|}
\hline Country & Status & Project & $\begin{array}{c}\text { Value } \\
\text { (\$) }\end{array}$ & Remarks \\
\hline Hungary & FIN & Huawei Logistics Center & $1.5 \mathrm{mln}$ & FIN \\
\hline Iran & FIN & $\begin{array}{c}\text { Dam and hydro-power plant Rudbar } \\
\text { Lorestan }\end{array}$ & $578 \mathrm{mln}$ & FIN \\
\hline Kazakhstan & FIN & $\begin{array}{c}\text { Horgos - railway junction and } \\
\text { transhipment point at the border, } \\
\text { where there is a change in the width } \\
\text { of the railway track }\end{array}$ & $245 \mathrm{mln}$ & FIN \\
\hline Pakistan & FIN & $\begin{array}{c}\text { Gwadar - expansion of the seaport - } \\
\text { stage I (breakwater) }\end{array}$ & $123 \mathrm{mln}$ & $\begin{array}{l}\text { FIN (a planned key transport hub } \\
\text { connecting Pakistan with } \\
\text { Afghanistan and Central Asia; also } \\
\text { planned: special zones for the } \\
\text { development of trade and industry } \\
\text { related to export development. } \\
\text { (Potential military significance is of } \\
\text { concern in some countries, but } \\
\text { local authorities only confirm the } \\
\text { commercial profile of the project.) }\end{array}$ \\
\hline Sri Lanka & FIN & & $1.3 \mathrm{mln}$ & FIN \\
\hline
\end{tabular}

(continued) 


\section{Continued}

\begin{tabular}{|c|c|c|c|c|}
\hline Country & Status & Project & $\begin{array}{c}\text { Value } \\
\text { (\$) }\end{array}$ & Remarks \\
\hline & & $\begin{array}{l}\text { Expansion of Hambantota seaport, } \\
\text { stages I and II }\end{array}$ & & \\
\hline Cambodia & FIN & \begin{tabular}{|} 
Modernization of National Road No. \\
$214 ;$ Treng-Mekong Bridge
\end{tabular} & $117 \mathrm{mln}$ & FIN \\
\hline Indonesia & FIN & Sumsel-5 Power Plant & $318 \mathrm{mln}$ & FIN \\
\hline $\begin{array}{l}\text { North } \\
\text { Korea }\end{array}$ & FIN & New Yalu Bridge & $350 \mathrm{mln}$ & FIN \\
\hline Bangladesh & UC & Payra Power Plant & $1.7 \mathrm{mln}$ & \\
\hline Bangladesh & PREP & Dhaka - Jessore railway line & $4.4 \mathrm{mln}$ & \\
\hline Bangladesh & PREP & The Karnaphuli Tunnel & $?$ & \\
\hline Laos & UC & China - Laos Rail Link & $5.8 \mathrm{mln}$ & \\
\hline Laos & UC & Hydro-project Nam Ou (phase II) & $2.8 \mathrm{mln}$ & \\
\hline Laos & $?$ & Road connection Phongsaly - Yunnan & $910 \mathrm{mln}$ & \\
\hline Israel & START & Port of Haifa Bay & $1.2 \mathrm{mln}$ & \\
\hline Mongolia & NEG & Tavan - Tolgoi railway line & $1 \mathrm{mln}$ & \\
\hline Turkey & NEG & 3. nuclear power plant & $25 \mathrm{mln}$ & \\
\hline Ukraine & NEG & 4th Metro line in Kiev & $1.3 \mathrm{mln}$ & \\
\hline Indonesia & PREP & $\begin{array}{c}\text { Jakarta high-speed railway line - } \\
\text { Bandung }\end{array}$ & $6 \mathrm{mln}$ & $\begin{array}{l}\text { Significant delays in the } \\
\text { implementation of the project, } \\
\text { increase in costs due to the } \\
\text { increase of inland prices. }\end{array}$ \\
\hline Indonesia & START & Monado - Bitung a toll highway & $370 \mathrm{mln}$ & \\
\hline Pakistan & NEG & Kohala Hydro-Power Plant & $2.4 \mathrm{mln}$ & \\
\hline Pakistan & START & $\begin{array}{l}\text { Aurostrada Peshawar - Karachi } \\
\text { (Multan - Sukkur section) }\end{array}$ & $2.8 \mathrm{mln}$ & \\
\hline Sri Lanka & START & $\begin{array}{c}\text { Matara - Kataragama railway line } \\
\text { (phase I: Matara section - Beliatta) }\end{array}$ & $?$ & \\
\hline
\end{tabular}

Source: Based on Yamada, G. - Palma, S. (2018), and information taken from several editions of The Economist (2018).

Notes: FIN - completed, closed; UC - during construction; START - started; PREP - preparatory phase; NEG publicly advertised project, still partly in the negotiation phase. 